\title{
PERAN GURU EKSTRAKURIKULER DALAM MENGEMBANGKAN \\ BAKAT SISWA DI MI MIFTAHUL ULUM 02 GUMUKREJO KARANGSONO BANGSALSARI JEMBER
}

\author{
Ni'mah Lailatul Mas'adah \\ Institut Agama Islam Syarifuddin Lumajang, Indonesia \\ e-mail: nikma365@gmail.com \\ Ali Murtadlo \\ Institut Agama Islam Syarifuddin Lumajang, Indonesia \\ e-mail: alimurtadloqqq@gmail.com
}

\begin{abstract}
ABSTRAK
Salah satu peran guru dalam mengembangkan bakat anak adalah dengan cara membantu pribadi anak baik dari sisi kemandirian, membimbing dan mendorong bakat dan aspek-aspek kepribadian kemasyarakatan. Khsuusnya dalam mengembangkan keterampilan motorik melalui perencanaan pembimbingan dan penyediaan sarana penunjang yang memadai. Kegiatan yang menarik dalam pengembangan ini adalah melalui kegiatan ekstrakurikuler, seperti Qiroah, Pidato, dan Kaligrafi. Penelitian ini difokuskan terhadap peran guru ekstrakurikuler dalam mengembangkan bakat anak di MI Miftahul Ulum 02 Gumukrejo Karangsono Bangsalsari Jember yang menitikberatkan pada faktor pendukung dan penghambatnya. Penelitian ini menggunakan pendekatan kualitatif dengan penelitian studi kasus.

Peran Guru Ekstrakurikuler dalam Mengembangkan Bakat Anak memunculkan beberapa indikator keberhasilan melalui kegiatan ekstrakurikuler yang menjadi perhatian dan selalu diupayakan guru ekstrakurikuler adalah Qiroah, Pidato dan Kaligrafi; dengan di dukung oleh a) Guru memiliki semangat yang tinggi dan professional; b) Adanya sarana prasarana yang memadai; c) Antusiasme para guru dalam melakukan kerjasama kegiatan ekstrakurikuler; sedangkan penghambatnya adanya siswa yang hanya kengikuti kegitan tanpa ada resspon, seperti ketika kegiatan qiroah, mereka hanya mengikuti saja, tidak ada semangat untuk menunjukkan kemampuannya.
\end{abstract}

Keywords: Peran Guru, Ekstrakurikuler, Bakat Siswa 


\section{Pendahuluan}

Pada umumnya pembelajaran di sekolah masih terfokus pada guru, dan belum berpusat pada siswa (teacher centered). Pembelajaran di sekolah lebih bersifat menghafal atau pengetahuan faktual, hal ini menjadikan pembelajaran tidak searah dengan tujuan pendidikan Nasional. Salah satu tujuan pendidikan Nasional adalah untuk mengembangkan kecakapan berpikir siswa kritis, berpikir logis, sistematis, bersifat objektif, jujur dan disiplin dalam memandang dan menyelesaikan masalah yang berguna untuk kehidupan dalam masyarakat termasuk dunia kerja. Mata pelajaran hanyalah sebuah alat untuk mencapai tujuan, untuk dapat melatih siswa memiliki keterampilan berpikir. ${ }^{1}$

Peranan guru dalam mengajar dapat dikatakan sangat dominan, begitu pula dalam meningkatkan proses pembelajaran siswa tampaknya guru yang mengetahui akan kemampuan siswa-siswanya baik secara individual maupun secara kelompok, guru mengetahui persoalanpersoalan belajar dan mengajar, guru pula yang mengetahui kesulitankesuliatan siswa terhadap pelajaran dan bagaimana cara memecahkannya. Dari uraian di atas tampak bahwa proses pembelajaran merupakan hal yang sangat penting yang diperlukan oleh setiap siswa. Oleh karena itu seorang guru dituntut untuk bisa menumbuhkan dan meningkatkan minat belajar siswa dan dapat meningkatkan bakat siswa.

Peran guru sebagai komunikator yakni di mana guru sebagai tempat berkomunikasi bagi anak didiknya, dengan berkomunikasi antara dengan dan anak didik maka guru akan lebih bisa lebih memahami dan mengetahui kesulitan atau masalah-masalah yang di hadapi anak didiknya. motivator sangat penting dalam interaksi edukatif, karena

\footnotetext{
${ }^{1}$ Munir, 2009, Pembelajaran Jarak Jauh Berbasis Teknologi Informasi dan Komunikasi Bandung: Alfabeta, 1 .
} 
menyangkut esensi pekerjaan mendidik yang membutuhkan kemahiran sosial.

Adapun peran lain dari guru adalah menjadi pemberian nilai dan sikap kepada anak didik utamanya anak prasekolah, yaitu melalui tingkah laku atau perbuatan yang mencerminkan nilai dan sikap yang baik dan terpuji yang diharapkan dapat ditiru oleh anak didik. Dalam organisasi, peran guru adalah sebagai mitra pemerintah dan masyarakat untuk memberikan musukan-masukan dalam rangka mewujudkan pendidikan nasional. ${ }^{2}$

Upaya guru terhadap siswa adalah harus bisa memiliki tanggung jawab dan bisa memahami siswa agar dapat memberikan pendidikan, pengajaran dan bimbingan sebaik-baiknya dan seefektif mungkin. Guru merupakan profesi atau jabatan, pekerjaan yang merupakan keahlian khusus sebagai guru. Upaya guru dalam motivasi belajar sangat penting karena dengan memberikan motivasi maka tujuan proses belajar mengajar yang diharapkan akan tercapai.

Upaya guru dalam meningkatkan memotivasi belajar siswa dapat dilakukan dengan dua cara, yaitu motivasi instrinsik dan motivasi ekstrinsik. Motivasi intrinsik adalah keinginan bertindak yang disebabkan oleh faktor pendorong dari dalam diri (internal) individu, sedangkan motivasi ekstrinsik dapat juga di katakan sebagai bentuk motivasi yang di dalamnya aktivitas belajar di mulai dan diteruskan berdasarkan dorongan dari luar yang tidak secara mutlak berkaitan dengan aktivitas belajar. ${ }^{3}$

Adapun peran guru bukan hanya mengajar dan membimbing tetapi juga mengarahkan dan memberikan motivasi agar bakat-bakat yang

\footnotetext{
${ }^{2}$ Malik Fajar dkk, 2002, Mengggagas Pendidikan Masa Depan, Malang: FKIP UMM, 183.

3 Sardiman, 2008, Interaksi dan Motivasi Belajar Mengajar, Jakarta : PT. Raja Grafindo Persada, 90.
} 
dimiliki siswa bisa terwujud, karena guru adalah sosok sentral bagi kepribadian anak didik. mereka mendengarkan ucapan dan meneladani perilaku guru mereka. Dalam kontek penggalian dan pengemabngan bakat anak didik, peran guru sangat mencolok. Jadi mengembangkan bakat siswa dalam upaya pembinaan pribadi menuju pembinaan manusia seutuhnya yang positif. Dapat mengetahui, mengenal serta membedakan antara hubungan satu pelajaran dengan pelajaran lainnya. Salah satu hal yang dapat dilakukan guru dalam mengembangkan bakat anak adalah dengan cara membantu masing-masing anak agar berkembang pada tingkat kemandirian.

Bakat adalah kegiatan yang disenangi oleh anak-anak secara terus menerus dan disertai dengan minat yang kuat. Tentu kegiatan tersebut positif dan berguna, bukan yang negative dan tidak berguna, apa lagi merugikan dri sendiridan orang lain. ${ }^{4}$

Jamal Ma'mur Asmawi dalam buknya yang berjudul Kiat Mengembangkan Bakat Anak di Sekolah adalah bakat merupakan potensi yang dimilki oleh seseorang sebagai bawaan sejak lahir, bakat adalah suatu bentuk kemampuan khusus yang memungkinkan seseorang memperoleh keuntungan dari hasil pelatihannya sampai satu tingkat lebih tinggi. Bakat merupakan karakteristik unik individu yang membuatnya mampu melakukan suatu aktivitas dan tugas secara mudah dan sukses. ${ }^{5}$

Salah satu lembaga yang gurunya bukan hanya mengajar, tetapi juga menjadi motivator, fasilitator dan insirator dalam mengembangkan bakat siswanya adalah MI Miftahul Ulum 02 Gumukrejo Karangsono Bangsalsari . Salah satu kegiatan yang menarik dalam mengembangkan bakat siswa adalah melalui kegiatan ekstrakurikuler, seperti Qiroah,

${ }^{4}$ Iskandar Junaidi, 2011, Mencetak Anak Unggul, Yogyakarta: Andi, 21.

5 Jamal Ma'mur Asmawi, 2012, Kiat Mengembangkan Bakat Anak di Sekolah, Yogyakarta: Diva Perss, 21-22. 
Pidato, dan Kaligrafi. Kegiatan ini menjadi salah satu unsur penting dalam mengembangkan bakat siswa.

Dari hasil observasi awal peneliti bahwa dari beberapa bakat yang dimiliki siswa dibuktikan dengan adanya siswa berprestasi, seperti Siti Aminah juara 2 Qiroah tingkat Kecamatan, Muhammad Dahlan juara 1Kaligrafi tingkat Kecamatan, Ika idiawati juara 2 pidato tingkat kecamatan dan Budinoni juara harapan 1 kaligrafi tingkat kecamatan. ${ }^{6}$

Mengacu pada dasar pemikiran yang terdapat dalam latar belakang masalah di atas, maka dalam permasalahan tersebut terdapat fokus dan manfaat penelitian untuk mengetahui bagaimana peran guru ekstrakurikuler dalam mengembangkan bakat anak di MI Miftahul Ulum 02 Gumukrejo Karangsono Bangsalsari Jember tahun pelajaran 2018/2019, termasuk dari sisi faktor pendukung dan penghambatnya.

\section{Metodologi}

Untuk mencapai hasil yang maksimal, maka kerangka kerja setiap penelitian harus mengacu pada metode-metode yang sesuai dengan obyek yang di teliti, hal ini dilakukan supaya kegunaan penelitian agar berjalan dengan lancar dan hasilnya diakui oleh publik. Metode penilitian akan memandu si peneliti tentang sistematika sebuah penelitian yang di lakukan. ${ }^{7}$

\section{Pendekatan dan Jenis Penelitian}

Penelitian ini menggunakan penelitian kualitatif yaitu lebih mendeskripsikan data bukan untuk mengukur data yang diperoleh. Sedangkan jenis penelitian yang digunakan adalah studi kasus ini bersifat terancang artinya peneliti memusatkan perhatiannya pada kasus yang telah ditetapkan yakni tentang Peran guru ekstrakurikuler dalam

${ }^{6}$ Observasi, Jember 12 Maret 2019

${ }^{7}$ M. Nazir, Metode Penelitian (Jakarta : Galia Indonesia, 2003), 44. 
mengembangkan bakat anak di MI Miftahul Ulum 02 Gumukrejo Karangsono Bangsalsari Jember tahun pelajaran 2018/2019.

sumber data dalam penelitian ini memakai sumberdata subyek dari mana data dapat diperoleh. ${ }^{8}$ meliputi sumber data primer dan sumber data sekunder.

Data primer adalah data yang diperoleh secara langsung dari sumbernya untuk diamati dan dicatat dalam bentuk utama kalinya dan merupakan bahan utama penelitian. Melalu data yang diperoleh dari Kepala Sekolah, Guru ekstrakurikuler dan Siswa MI Miftahul Ulum 02 Gumukrejo Karangsono Bangsalsari Jember. Sementara sumber data sekunder adalah sumber data yang mendukung yang berupa bahanbahan perpustakaan dan dokumentasi yang berkenaan dengan peran guru ekstrakurikuler dalam mengembangkan bakat anak misalnya mengenai sejarah berdiri, struktur, jumlah guru, jumlah siswa, visi dan misi, kurikulum dan sebagainya yang diperoleh dari lingkungan MI Miftahul Ulum 02 Gumukrejo Karangsono Bangsalsari Jember tahun pelajaran 2018/2019.

\section{Teknik Pengumpulan Data}

Adapun teknik pengumpulan data yang digunakan adalah: Teknik observasi adalah pengamatan secara langsung terhadap obyek penelitian seperti peran guru ekstrakurikuler dalam mengembangkan bakat anak, teknik ini juga digunakan untuk mendapatkan informasi tentang peran guru ekstrakurikuler dalam mengembangkan bakat anak guna mengetahui faktor penghambat dan faktor pendukung, letak geografis, sarana prasarana dan lain-lain yang di miliki oleh MI Miftahul Ulum 02 Gumukrejo Karangsono Bangsalsari Jember. Selanjutnya peneliti menggunakan wawancara sebagai cara pengumpulan data yang

${ }^{8}$ Suharsimi Arikunto, Prosedur Penelitian (Jakarta : Renika Cipta, 2006),129. 
digunakan untuk memperoleh informasi langsung dari sumbernya, baik dalam bentuk tulisan ataupun lisan. Teknik ini untuk mendapatkan informasi tentang sejauh mana peran guru dalam membina siswanya melalui Kepala Sekolah, Guru ekstrakurikuler dan Siswa MI Miftahul Ulum 02 Gumukrejo Karangsono Bangsalsari Jember. Wawancara juga didukung dengan teknik dokumentasi yang digunakan untuk memperoleh data langsung dari tempat peneliti, yang digunakan untuk mendapatkan data tentang metode Jarimatika, jumlah pegawai, jumlah murid, jumlah kelas, keadaan guru, serta sejarah atau latar belakang berdirinya MI Miftahul Ulum 02 Gumukrejo Karangsono Bangsalsari Jember.

\section{Analisis Data}

Analisis data ini merupakan kerja penting dalam sebuah penelitian, karena hanya dengan melalui analisis data peneliti dapat mendeskripsikan, mengambil kesimpulan dan membuktikan sebuah teori atau hipotesis.

Adapun dalam proses analisa data, penulis menggunakan metode Hubermen dan Miells, yaitu: Reduksi data merupakan proses penyederhanaan dan transformasi data 'kasar' yang mucul dari data penulis di lapanga dengan melalui beberapa tahap yaitu membuat ringkasan, mengkode, menulis tema, membuat patris, membuat memo. Penyajian data yaitu informasi tersusun yang memberi kemungkinan adanya penarikan kesimpulan dan pengambilan tindakan. Verifikasi atau penarikan kesimpulan yaitu makna-makna yang muncul dari data yang lurus diuji kebenarannya, kekokohannya, dan kecocokannya yang merupakan faliditas dari data tersebut. ${ }^{9}$

\footnotetext{
${ }^{9}$ Hubermen, Michael dan Matehew, Analisis Data Kualitatif (Jakarta : Universitas Indonesia Press, 1992), 16.
} 


\section{Keabsahan Data}

Untuk menetapkan keabsahan (trustworthiness) data diperlukan tekhnik pemeriksaan. Pelaksanaan teknik pemeriksaan didasarkan atas sejumlah kriteria tertentu. Ada empat kriteria yang digunakan, yaitu: Derajat kepercayaan (credibility), Keteralihan (transferability), Kebergantungan (dependability), Kepastian (confermability). ${ }^{10}$

Setelah langkah-langkah tersebut dilakukan, langkah selanjutnya adalah melakukan penyederhanaan data serta diadakan perbaikan dari segi bahasa maupun sistematikanya agar dalam pelaporan hasil penelitian tidak diragukan lagi keabsahannya.

\section{Tahap-tahap Penelitian}

Adapun tahap-tahap penelitian yang dilakukan peneliti terdapat 3 tahapan, yaitu: Dalam tahap pra lapangan, peneliti melakukan survei ke MI Miftahul Ulum 02 Gumukrejo Karangsono Bangsalsari Jember untuk mendapatkan data tentang peran guru ekstrakurikuler dalam mengembangkan bakat anak.

Tahap kegiatan lapangan ini difokuskan pada hal-hal yang ingin diteliti, dalam hal ini peneliti menfokuskan pada peran guru ekstrakurikuler dalam mengembangkan bakat anak di MI Miftahul Ulum 02 Gumukrejo Karangsono Bangsalsari Jember.

Tahap analisis data adalah pengecekan data dari informasi, subyek studi maupun dokumen untuk membuktikan keabsahan data yang telah diperoleh, untuk penyederhanaan data serta untuk perbaikan data baik dari segi bahasa atau sistematika.

\section{Pembahasan}

Dalam pembahasan temuan ini akan dipaparkan data temuan peneliti tentang peran guru ekstrakurikuler dalam mengembangkan bakat

${ }^{10}$ Lexy J. Moleong, Metodologi Penelitian Kualitatif (Bandung : Remaja Rosda Karya, 2008) 324. 
anak di MI Miftahul Ulum 02 Gumukrejo Karangsono Bangsalsari Jember adalah sebagai berikut:

\section{Peran Guru Ekstrakurikuler dalam Mengembangkan Bakat Anak}

Sebagaimana hasil temuan peneliti bahwa peran guru ekstrakurikuler dalam mengembangkan bakat anak di MI Miftahul Ulum 02 Gumukrejo Karangsono Bangsalsari Jember tahun pelajaran 2018/2019 adalah sebagai berikut: Guru Ekstrakurikuler sebagai tauladan atau figur dalam mengembangkan bakat anak. Dalam mengembangkan bakat anak yang dilakukan oleh guru ekstrakurikuler adalah dengan cara memberikan ketauladanan, yakni guru berperan sebagai tauladan atau figur bagi siswanya, karena guru merupakan figur pertama yang dipandang oleh siswa dalam mengembangkan bakatnya. Salah satu contoh yang diterapkannya adalah dengan selalu memberikan pemahaman dan contoh terhadapa bakat-bakat yang dimiliki siswa, seperti memberikan contoh cara qiroah yang enak, cara membuat kaligrafi dan bagaimana berpidato yang bisa membuat pendengar senagat dan mengembirakan.

Dalam mengembangkan bakat anak yang dilakukan oleh guru ekstrakurikuler adalah dengan cara memberikan contoh bagai anak. Dengan pemberian contoh ini karena guru ekstakurikuler merupakan figur utama yang akan dinilai oleh para sisiwa dan merupakan tanggung bagi seorang guru.

Peran Guru ekstrakurikuler sebagai pembimbing dalam mengembangkan bakat anak adalah dengan cara memberikan bimbingan atau arahan kepada siswa, khususnya kepada siswa yang ingin mengembangkan bakatnya dalam bidang keagaaman seperti kaligrafi, qiroah dan pidato. Cara yang dilakukan adalah dengan memberikan suatu bimbingan kepada siswa tentang bagaimana seharusnya ia bertindak, mempraktekkan dan memberikan kritik dalam mengembangkan bakatnya sehingga siswa lebih termotivasi dan senang 
untuk mengembangkan bakatnya. Adapun peran guru ekstrakurikuler sebagai pembimbing tersebut dilakukan dengan cara memberi pelajaran membuat kaligrafi yang sesuai dengan metodenya, melakukan qiroah sesuai dengan mimik dan intonasi yang benar, memberikan contoh pidato yang benar.

Guru ekstrakurikuler berperan sebagai pembimbing atau pendidik yang dilakukan dengan cara memberikan arahan kepada siswa tentang cara mengembangkan bakat siswa, tanggung jawab seorang siswa, kewajiban seorang siswa serta kebiasaan khususnya bakat yang berkaitan dengan keagamaan, seperti bakat siswa berkaitan dengan pidato, kaligrafi dan qiroah. Contoh peran ekstakurikuler sebagai pendidik adalah selalu memberikan suatu tauladan yang baik kepada siswanya, baik berupa tingkah laku, perkataan dan perbuatan dan memberikan pendidikan bagaimana berpidato yang baik, membuat kaligrafi yang benar dan qiroah yang benar.

Berdasarkan beberapa temuan tersebut maka dapat disimpulkan bahwa peran guru ekstrakurikuler dalam mengembangkan bakat anak di MI Miftahul Ulum 02 Gumukrejo Karangsono Bangsalsari Jember tahun pelajaran 2018/2019 adalah sebagai pembimbing dan sebagai figure atau tauladan, yang ini dilakukan dengan cara guru mengajak siswa dalam kegiatan ekstrakurikuler Agama Islam yang sesuai dengan keinginan siswa. Dalam kegiatan ekstrakurikuler ini tidak ada paksaan dari guru untuk mengukutinya, hanya saja siapa yang berminat bisa mendaftarkan diri untuk mengikuti kegiatan tersebut. Kegiatan ini dilaksanakan di luar jam pelajaran. Jadi peran guru ekstrakurikuler dalam mengembangkan bakat anak di MI Miftahul Ulum 02 Gumukrejo Karangsono Bangsalsari Jember adalah dilakukan dengan motivasi, yaitu sebagai motivasi yang timbul dari dalam diri siswa tanpa ada paksaan atau dorongan dari guru atau orang lain, tetapi atas dasar kemauan sendiri. Cara yang dilakukan 
guru ekstrakurikuler adalah menyampaikan kepada siswa tentang kegiatan ekstrakurikuler yang akan dilaksanakan. Kemudian siswa yang ingin belajar seperti belajar qiroah langsung bisa mendaftar, keinginan siswa tersebut karena memang dia ingin mendapatkan pengetahuan dan ilmu tentang qiroah. Itulah sebabnya bimbingan dan motivasi yang dilakukan guru ekstrakurikuler sebagai bentuk motivasi yang di dalamnya aktivitas belajar dimulai dan diteruskan berdasarkan dorongan dari dalam diri dan secara mutlak terkait dengan aktivitas belajarnya.

\section{Faktor Pendukung Peran Guru Ekstrakurikuler dalam Mengembangkan}

\section{Bakat Anak}

Sebagaimana hasil temuan peneliti bahwa faktor pendukung peran guru ekstrakurikuler dalam mengembangkan bakat anak di MI Miftahul Ulum 02 Gumukrejo Karangsono Bangsalsari Jember tahun pelajaran 2018/2019 adalah: Guru ekstrakurikuler yang memiliki semangat yang tinggi dan profesional. Guru ekstrakurikuler yang profesional merupakan kebutuhan yang harus dimiliki, dan tidak bisa ditawar-tawar, adapun guru ekstrakurikuler yang professional ini adalah guru yang professional sesuai dengan kebutuhannya, seperti: penguasaan materi, bisa menerapkan praktik syari'ah, cepat tanggap dan semangat guru ekstrakurikuler tinggi untuk membiasakan siswa melaksankan setiap kegiatan, baik dalam kegiatan intra dan kegiatan ekstrakurikuler.

Adanya sarana prasarana yang memadai. Sarana dan prasarana dalam suatu lembaga sangat penting karena tanpa adanya sarana prasarana yang cukup maka pendidikan tidak akan berjalan dengan lancar. Dari hasil penelitian sarana prasarana yang dapat mendukung faktor pendukung peran guru ekstrakurikuler dalam mengembangkan bakat anak di MI Miftahul Ulum 02 Gumukrejo Karangsono Bangsalsari Jember tahun pelajaran 2018/2019 adalah adanya Al-Qur'an di tiap kelas, 
adanya perpustakaan yang sebagian berisi kitab-kitab dan terjemah serta banyaknya buku fiqih, alat peraga, bahan praktik dan lain-lain.

Antusiasme para guru dalam melakukan kerjasama kegiatan ekstrakurikuler. Adapun dari hasil observasi peneliti dilapanan bahwa salah satu faktor pendukung peran guru ekstrakurikuler dalam mengembangkan bakat anak di MI Miftahul Ulum 02 Gumukrejo Karangsono Bangsalsari Jember tahun pelajaran 2018/2019 adalah adanya kerjasama antar guru, seperti ketika kegiatan ekstrakurikuler dilakukan, semua guru ikut terlibat, ketika mengadakan lomba pidato, kebanyakan para guru ikut andil untuk mensukseskan tujuan dari kegiatan tersebut.

\section{Faktor Penghambat Peran Guru Ekstrakurikuler dalam Mengembangkan Bakat Anak}

Sebagaimana hasil temuan peneliti ketika kegiatan ekstrakurikuer berlangsung, bahwa faktor penghambat peran guru ekstrakurikuler dalam mengembangkan bakat anak di MI Miftahul Ulum 02 Gumukrejo Karangsono Bangsalsari Jember tahun pelajaran 2018/2019 adanya siswa yang hanya kengikuti kegitan tanpa ada resspon, seperti ketika kegiatan qiroah, mereka hanya mengikuti saja, tidak ada semangat untuk mengeluarkan kemampuannya, sehingga dengan adanya tersebut peran guru ekstrakurikuler dalam mengembangkan bakat anak kurang bisa memberikan peningkatan dalam pengembangan bakat siswa. Namun setelah satu bulan dari peneliti awal ada perubahan strategi yang bisa membuat para siswa sama-sama aktif. Adapun contoh yang telah dterapkan ketika mengadakan kaligrafi dan pidato, guru ekstrakurikuler ikut andil dengan cara mendatangi satu persatu siswa yang sedang mengerjakan kaligrafi. Dalam hal pidato guru langsung memberikan contoh cara berpidato yang benar dan dapat menarik minat pendengar. 


\section{Kesimpulan}

Berdasarkan hasil temuan peneliti dengan kajian teori dapat disimpulkan bahwa terdapat kesamaan tentang faktor penghambat peran guru ekstrakurikuler dalam mengembangkan bakat anak adalah hanya saja kurang adanya semangat dari siswa dan terkadang guru kurang menyenangkan dan mengesankan.

Peran Guru Ekstrakurikuler dalam Mengembangkan Bakat Anak di MI Miftahul Ulum 02 Gumukrejo Karangsono Bangsalsari adalah a) Peran Guru Ekstrakurikuler sebagai tauladan atau figur dalam mengembangkan bakat anak, karena guru merupakan figur pertama yang dipandang oleh siswa dalam mengembangkan bakatnya. Salah satu contoh yang diterapkannya adalah dengan selalu memberikan pemahaman dan contoh terhadapa bakat-bakat yang dimiliki siswa, seperti memberikan contoh cara qiroah yang enak, cara membuat kaligrafi dan bagaimana berpidato yang bisa membuat pendengar senagat dan mengembirakan; b) Peran Guru ekstrakurikuler sebagai pembimbing dalam mengembangkan bakat anak yang dilakukan dengan cara memberikan arahan kepada siswa tentang cara mengembangkan bakat siswa, tanggung jawab seorang siswa, kewajiban seorang siswa serta kebiasaan khususnya bakat yang berkaitan dengan keagamaan, seperti bakat siswa berkaitan dengan pidato, kaligrafi dan qiroah. Sementara faktor pendukung peran Guru Ekstrakurikuler dalam Mengembangkan Bakat Anak adalah: a) Guru ekstrakurikuler yang memiliki semangat yang tinggi dan professional sesuai dengan kebutuhannya, seperti: penguasaan materi, bisa menerapkan praktik syari'ah, cepat tanggap dan semangat guru ekstrakurikuler tinggi untuk membiasakan siswa melaksanakan setiap kegiatan, baik dalam kegiatan intra dan kegiatan ekstrakurikuler; b) Adanya sarana prasarana yang memadai, seperti adanya Al-Qur'an di tiap kelas, adanya perpustakaan yang sebagian berisi kitab-kitab dan 
terjemah serta banyaknya buku fiqih, alat peraga, bahan praktik dan lainlain; c) Antusiasme para guru dalam melakukan kerjasama kegiatan ekstrakurikuler, seperti ketika kegiatan ekstrakurikuler dilakukan, semua guru ikut terlibat, ketika mengadakan lomba pidato, kebanyakan para guru ikut andil untuk mensukseskan tujuan dari kegiatan tersebut.

Sementara faktor penghambat peran guru ekstrakurikuler dalam mengembangkan bakat anak di MI Miftahul Ulum 02 Gumukrejo Karangsono Bangsalsari Jember adalah adanya siswa yang hanya kengikuti kegitan tanpa ada resspon, seperti ketika kegiatan qiroah, mereka hanya mengikuti saja, tidak ada sengat untuk mengeluarkan kemampuannya, sehingga dengan adanya tersebut peran guru ekstrakurikuler dalam mengembangkan bakat anak kurang bisa memberikan peningkatan dalam pengembangan bakat siswa. Namun setelah satu bulan dari peneliti awal ada perubahan strategi yang bisa membuat para siswa sama-sama aktif. Adapun contoh yang telah dterapkan ketika mengadakan kaligrafi dan pidato, guru ekstrakurikuler ikut andil dengan cara mendatangi satu persatu siswa yang sedang mengerjakan kaligrafi. Dalam hal pidato guru langsung memberikan contoh cara berpidato yang benar dan dapat menarik minat pendengar.

\section{Daftar Pustaka}

Amir Hadi dan Haryono, 2015, Metodologi Penelitian Pendidika, Bandung : Pustaka Setia.

Asmawi, Jamal Ma'mur, 2012, Kiat Mengembangkan Bakat Anak di Sekolah, Yogyakarta: Diva Perss.

Fajar, Malik dkk, 2002, Mengggagas Pendidikan Masa Depan, Malang: FKIP UMM.

Hubermen, A. Michael dan Matehew, 1992, Analisis Data Kualitatif, Jakarta: Universitas Indonesia Press.

Jamarah, Saiful Bahri, 2002, Psikologi Belajar, Jakarta: PT Rineka Cipta. 
Junaidi, Iskandar, 2011, Mencetak Anak Unggul. Yogyakarta: Andi.

Munir, 2009, Pembelajaran Jarak Jauh Berbasis Teknologi Informasi dan Komunikasi, Bandung: Alfabeta.

Saebani, Beni Ahmad, 2008, Metode Penelitian, Bandung: Pustaka Setia.

Fajar, Malik dkk., 2002, Mengggagas Pendidikan Masa Depan, Malang: FKIP UMM.

Moleong, Lexy J., 2008, Metodologi Penelitian Kualitatif Edisi Revisi, Bandung: PT. Remaja Rosdakarya.

Muhajir, Moeni. 1989. Metodologi Penelitian Kualitatif. Yogyakarta: Raka Serasih.

Sugiyono. 2007. Metode Penelitian Kuantitatif dan RED. Bandung: Alfabeta.

Saebani, Beni Ahmad. 2008. Metode Penelitian. Bandung: Pustaka Setia.

Usman, Moh Uzer. 2004. Menjadi Guru Professional. Bandung: PT. Remaja roesdekarya. 